\title{
PENURUNAN GLUKOSA DARAH MENCIT (MUS MUSCULUS) JANTAN HIPERGLIKEMIA DENGAN VARIASI PENAMBAHAN MINUMAN SERBUK BIJI ALPUKAT (PERSEA AMERICANA MILL.)
}

\section{Decrease of Blood Sugar in Hyperglycemic Male Mice (Mus musculus) With Various Addition of Avocado (Persea americana Mill.) Seed Powder Drink}

\author{
Stefanie Glorina Iskandar ${ }^{1}$, Yuliana Reni Swasti ${ }^{*}$, Yanuartono ${ }^{2}$ \\ ${ }^{1}$ Fakultas Teknobiologi - Universitas Atma Jaya Yogyakarta - Jalan Babarsari 44 - Yogyakarta 55281 \\ 2Departemen Ilmu Penyakit Dalam - Fakultas Kedokteran Hewan - Universitas Gadjah Mada Yogyakarta, \\ Jalan Fauna No. 2 - Karangmalang - Yogyakarta 55281 \\ *Penulis Korespondensi: email reni.swasti@uajy.ac.id; yulianareni@gmail.com
}

Disubmit: 6 Juni 2018 Direvisi: 30 Juli 2019 Diterima: 3 Nopember 2019

\begin{abstract}
ABSTRAK
Biji buah alpukat (Persea americana Mill.) merupakan salah satu biji yang memiliki kemampuan antihiperglikemia. Tujuan penelitian ini adalah mengetahui kemampuan minuman serbuk biji alpukat beserta dosis yang paling baik dalam menurukan kadar glukosa darah dan berat badan mencit (Mus musculus) hiperglikemia yang diinduksi aloksan. Penelitian ini menggunakan Rancangan Acak Lengkap Faktorial dengan 3 dosis minuman serbuk biji alpukat $(180 \mathrm{mg} / \mathrm{kgBB}$, $360 \mathrm{mg} / \mathrm{kgBB}, 540 \mathrm{mg} / \mathrm{kgBB})$ dan kontrol positif $(0 \mathrm{mg} / \mathrm{kgBB})$. Rata-rata Kadar glukosa darah dan berat badan mencit sebelum diberi aloksan berturut-turut sebesar $152 \mathrm{mg} / \mathrm{dL}$ dan 23,85 g. Rata-rata kadar glukosa darah dan berat badan mencit setelah diberi aloksan secara berturut-turut sebesar $230,45 \mathrm{mg} / \mathrm{dL}$ dan $36,8 \mathrm{~g}$. Pemberian minuman serbuk biji alpukat dilakukan setiap hari selama lima minggu. Pengukuran kadar glukosa darah mencit hiperglikemia dilakukan setiap seminggu setelah pemberian minuman. Hasil penelitian menunjukkan bahwa minuman serbuk biji alpukat secara signifikan mampu menurunkan kadar glukosa darah mencit hiperglikemia. Perlakuan terbaik pada penelitian ini adalah pemberian minuman serbuk biji alpukat dosis $540 \mathrm{mg} / \mathrm{kgBB}$ yang dapat menurunkan kadar glukosa darah sebesar $44 \%$ dan berat badan sebesar $27,32 \%$.
\end{abstract}

Kata Kunci: Aloksan; Berat Badan; Dosis; Hiperglikemia

\begin{abstract}
Avocado (Persea Americana Mill.) seed is a seed that has antihyperglychemic ability. The purpose of this research is to know the ability of avocado seed powder drink and the best dosage in decreasing blood glucose level and weight of alloxan-induced hyperglycemia mice (Mus musculus). This study was conducted using a Factorial Completely Randomized Design with 3 doses avocado seed powder drink $(180 \mathrm{mg} / \mathrm{kgBB}$, $360 \mathrm{mg} / \mathrm{kgBB}, 540 \mathrm{mg} / \mathrm{kgBB}$ ) and 1 positive control $(0 \mathrm{mg} / \mathrm{kgBB})$. Average blood glucose and body weight of mice before given alloxan were $152 \mathrm{mg} / \mathrm{dL}$ and $23.85 \mathrm{~g}$. Average blood glucose and body weight of mice after given alloxan were $230.45 \mathrm{mg} / \mathrm{dL}$ and $36.8 \mathrm{~g}$. Powder drink is given every day for five weeks. Measurement of blood glucose levels of hyperglycemia mice taken every week. The results showed that the powder drink significantly reduced blood glucose levels of hyperglycemia mice. The best dose in this research is $540 \mathrm{mg} /$ $\mathrm{kgBB}$ which can decrease blood glucose level by $44 \%$ and decrease weight by $27.32 \%$.
\end{abstract}

Keywords: Alloxan; Weight; Dosage; Hyperglycemia 


\section{PENDAHULUAN}

Hiperglikemia adalah kondisi kadar glukosa dalam darah melebihi batas kadar glukosa normal, terjadi karena kurangnya insulin, sehingga kadar glukosa menjadi tinggi. Apabila terjadi terus menerus dan berlangsung dalam waktu yang lama, akan mengakibatkan diabetes melitus. Diabetes melitus merupakan sindrom, ditandai dengan hiperglikemia kronik dan gangguan metabolisme karbohidrat, protein, dan lemak (Dalimartha, 2005).

Salah satu biji buah yang memiliki kemampuan antihiperglikemia adalah biji alpukat (Persea americana Mill.). Biji alpukat mengandung senyawa metabolit seperti fenolik, dan flavonoid (Shehata dan Soltan, 2013). Selain senyawa tersebut, tanin, memiliki kemampuanantihiperglikemia, mengkerutkan membran epitel usus, menyebabkan berkurangnya penyerapan sari makanan, sehingga laju peningkatan glukosa darah tidak tinggi (Dalimartha, 2005).

Pembuatan minuman serbuk biji alpukat sangat memudahkan konsumen dalam menkonsumsinya. Pemilihan minuman serbuk sebagai sampel pada penelitian ini dikarenakan jangka waktu penyimpanannya lebih lama dibandingkan sampel yang lain, dan kandungan senyawa pada minuman serbuk dapat diatur konsentrasinya. Penelitian tentang minuman serbuk dari biji alpukat sebagai antihiperglikemia belum pernah dilaporkan, maka pada penelitian ini akan dilakukan Penentuan secara bioassay terhadap biji alpukat untuk mengetahui aktivitas antihiperglikemianya.

\section{METODE}

Bahan yang digunakan pada penelitian ini adalah biji alpukat (Persea americana Mill.) matang, kertas saring, asam galat, alkohol $70 \%$, akuades, reagen folin ciocalteu, larutan $\mathrm{Na}_{2} \mathrm{CO}_{3}$, eter, medium plate count agar, medium bile green lactose broth, mencit, alloxan monohydrate merk sigma aldrich, dan glukostrip.

Alat yang digunakan pada penelitiajn ini adalah parutan, oven merk Ventricell dan Maksindo, pisau, blender, ayakan, inkubator shaker merk JJSR, pengaduk, propipet, pipet ukur, bunsen, sendok, vortex merk Maxi Mix, tabung reaksi, rak tabung reaksi, spektrofotometer merk Thermofischer, laminair flow merk Airtech, corong, gelas ukur, timbangan digital, eksikator, Erlenmeyer, spray dryer merk Labplant, moisture balancing merk Phoenix Instrument, cawan porselen, tanur merk Furnace, color reader merk Konika Minolta, diagram kromatisitas CIE, cawan petri, mikro pipet, tip, jarum oral, syringe, mikrohematokrit, blender merk Philips dan glukometer merk Dr. Gluco.

\section{Preparasi Biji Alpukat dan Ekstraksi Tepung Biji Alpukat}

Buah alpukat dipilih yang matang kemudian biji dipisahkan dari buahnya dan dibersihkan dari kulit bijinya. Setelah dibersihkan, biji kemudian dicuci menggunakan air mengalir dan ditiriskan hingga bebas air. Biji alpukat yang telah ditiriskan dikecilkan ukurannya, dikeringkan dengan oven, dan dihaluskan menggunakan blender. Biji alpukat yang telah halus diayak menggunakan ayakan 60 mesh dan dilakukan ekstraksi selama 24 jam pada suhu ruang menggunakan inkubator shaker dengan air sebagai pelarutnya dengan perbandingan sampel dan air adalah 1:10. Ekstrak kemudian dipisahkan dari ampasnya menggunakan kertas saring.

\section{Pengujian Kandungan Kimia Ekstrak Tepung Biji Alpukat}

Ekstrak tepung biji alpukat ditentukan total fenolik menggunakan metode folin ciocalteau, dengan menggunakan standar asam galat. Pengujian total tanin pada ekstrak tepung biji alpukat dilakukan dengan ekstrak $0,4 \mathrm{ml}$ ditambahkan dengan reagen folin 0,4 $\mathrm{ml}$, dihomogenkan dan didiamkan selama 5 menit, kemudian ditambahkan $\mathrm{Na}_{2} \mathrm{CO}_{3} 7 \%$ sebanyak $4 \mathrm{ml}$ dan dihomogenkan. Ekstrak kemudian didiamkan pada ruang gelap selama 1 jam, serapan diukur pada panjang gelombang $750 \mathrm{~nm}$ dan kadar total fenolik dihitung dengan asam galat (Barku et al., 2013).

Pengujian total tanin dilakukan dengan metode folin ciocalteau, dengan standar asam tanat. Pengujian total tanin pada ekstrak tepung biji alpukat dilakukan dengan ekstrak ditambahkan reagen folin $1 \mathrm{ml}$ dan $\mathrm{Na}_{2} \mathrm{CO}_{3}$ $20 \% \quad 4 \mathrm{ml}$ dan dihomogenkan. Setelah dihomogenkan, sampel didiamkan pada ruang gelap selama 30 menit, kemudian 
serapan diukur pada panjang gelombang 725 $\mathrm{nm}$ dan kadar total tanin dihitung dengan asam tanat (Schanderl, 1970).

Pengujian saponin dilakukan secara kualitatif. Ekstrak $10 \mathrm{ml}$ dikocok selama 30 detik. Pengamatan dilakukan terhadap terbentuk atau tidaknya busa pada permukaan ekstrak. Hasil positif ditandai dengan terbentuknya busa stabil setinggi 1 - 3 (Harborne, 1987).

\section{Pembuatan Minuman Serbuk Biji Alpukat}

Proses pembuatan minuman serbuk biji alpukat dilakukan dengan mencampurkan ekstrak dengan maltodekstrin sebanyak 10\% dari ekstrak. Campuran kemudian dikeringkan menggunakan spray dryer. Suhu inlet yang digunakan pada spray dryer sebesar $100{ }^{\circ} \mathrm{C}$ dan suhu outlet sebesar $32{ }^{\circ} \mathrm{C}$.

\section{Pengujian Kandungan Kimia Minuman Serbuk Biji Alpukat}

Pengujian kandungan kimiawi minuman serbuk biji alpukat terdiri atas Pengujian total fenolik, total tanin, total saponin, kadar air, dan kadar abu. Pengujian total fenolik, total tanin, dan total saponin memiliki metode yang sama dengan Pengujian ekstrak tepung biji alpukat. Pengujian kadar air dan abu menggunakan metode gravimetrik (AOAC, 1995).

\section{Pengujian Fisik Minuman serbuk Biji Alpukat}

Pengujian fisik minuman serbuk terdiri atas pengujian warna dan daya larut. Pengujian warna secara kromameter menggunakan instrument color reader dengan parameter $\mathrm{L}$, $\mathrm{a}$, dan $\mathrm{b}$ yang diubah menjadi nilai $\mathrm{X}$ dan $\mathrm{Y}$ untuk menentukan warna minuman serbuk biji alpukat sesuai dengan diagram kromatisitas CIE. Pengujian daya larut menggunakan pelarut air dengan perbandingan sampel dengan pelarut adalah 1 :10. Sampel dilarutkan hingga larut sempurna.

\section{Pengujian Mikrobiologis Minuman serbuk Biji Alpukat}

Pengujian mikrobiologis minuman serbuk biji alpukat terdiri atas pengujian angka lempeng total (ALT) dengan metode pour plate dan pengujian koliform. Pengujian ALT, sampel dibuat pengenceran dari $10^{-1}$ hingga $10^{-3}$, kemudian masing-masing pengenceran dimasukkan ke dalam cawan petri dan ditambahkan medium plate count agar. Inkubasi selama 48 jam pada suhu $37^{\circ} \mathrm{C}$, koloni yang terbentuk dihitung (Rustan, 2013). Pengujian koliform, sampel dibuat pengenceran dari $10^{-1}$ hingga $10^{-3}$, masingmasing pengenceran dimasukkan ke dalam tabung reaksi yang berisi medium bile green lactose broth dengan tabung durham. Inkubasi dilakukan selama 48 jam pada suhu $37{ }^{\circ} \mathrm{C}$, koloni yang terbentuk dicocokkan dengan tabel most probable number (Fardiaz dan Margino, 1993).

\section{Pengujian Antihiperglikemik Minuman serbuk Biji Alpukat Pada Mencit Hiperglikemia}

Pengujian ini menggunakan 20 ekor mencit berbobot 20-25 gram dengan usia \pm 2 bulan. Mencit di aklimatisasi selama 1 minggu dalam ruangan yang memiliki ventilasi yang cukup. Mencit diberi pakan AD II Comfeed 591 sebanyak 21 gram setiap harinya dengan minum air putih. Mencit yang memenuhi syarat untuk diuji, dipuasakan terlebih dahulu selama 24 jam, dan aloksan diberikan secara intraperitoneal dengan dosis $130 \mathrm{mg} / \mathrm{kgBB}$. Mencit diberi 4 pelakuan berbeda yakni 3 dosis minuman serbuk biji alpukat (180 $\mathrm{mg} / \mathrm{kgBB}, 360 \mathrm{mg} / \mathrm{kgBB}, 540 \mathrm{mg} / \mathrm{kgBB}$ ) dan kontrol positif $(0 \mathrm{mg} / \mathrm{kgBB})$ dengan $5 \mathrm{kali}$ ulangan (ethical clearance nomor: 13.04/IV/LPPT-UGM/2017).

Pemberian minuman serbuk dilakukan setiap hari sekali sesaat setelah hiperglikemia atau sesaat setelah diberikan aloksan secara oral menggunakan gavage needle. Sebelum dilakukan pengukuran kadar glukosa darah, dilakukan pembiusan hewan uji dengan eter yang digunakan sebanyak $0,5 \mathrm{ml}$ (onset $= \pm 32$ detik; dengan durasi \pm 1 menit). Pengambilan darah pada mata menggunakan mikrohematokrit, dan dianalisis dengan glukometer, bagian yang dilukai dibersihkan dengan alkohol 70\%. Pengecekkan kadar glukosa darah dilakukan pada minggu ke-1, ke-2, ke-3, ke-4, dan ke-5.

\section{Analisis Data}

Data yang diperoleh dianalisis dengan menggunakan uji ANOVA, dan untuk mengetahui letak beda nyata antar perlakuan dilakukan Duncan's Multiple Range Test (DMRT) pada tingkat kepercayaan 95\%. Data diproses dengan menggunakan program SPSS versi 24 . 


\section{HASIL DAN PEMBAHASAN}

\section{Karaktersistik Ekstrak Tepung Biji Alpukat}

Tujuan dari analisa total fenolik, total tanin, dan total saponin ekstrak tepung biji alpukat adalah untuk mengetahui total fenol, total tanin, dan adanya keberadaan saponin pada ekstrak tepung biji alpukat.

Analisa tepung biji alpukat menunjukkan hasil total fenolik biji alpukat (303,8 mg GAE/100 g tepung biji alpukat) lebih rendah dibandingkan hasil penelitian Rifai dkk. (2018) yakni 803,46 mg GAE/100 g biji alpukat. Hasil yang lebih rendah disebabkan karena penelitian Rifai dkk. mengalami perebusan sebelum pengeringan serta penggunaan aseton sebagai pelarut. Pada penelitian ini menggunakan metode ekstraksi selama 24 jam dan air sebagai pelarut.

Tepung biji alpukat menunjukkan hasil total tanin biji alpukat lebih rendah $(8,2 \%$ dalam $1 \mathrm{~g} / 100 \mathrm{ml}$ ) dibandingkan penelitian Malanggi dkk. (2012) sebesar 11,7\%. Hal ini disebabkan karena konsentrasi tepung biji alpukat yang digunakan lebih besar 2 kali perbandingannya (1:10) dibandingkan penelitian Malanggi dkk. (1:5). Selain itu, pada penelitian Malanggi dkk menggunakan etanol sebagai pelarutnya, sedangkan pada penelitian ini menggunakan air sebagai pelarutnya.

Tepung biji alpukat menunjukkan hasil positif pada saponin, hal ini sesuai dengan penelitian yang dilakukan oleh Sunusmo (2018), yang menunjukkan biji alpukat positif mengandung saponin.

\section{Karakteristik Kimia, Fisik dan Mikrobiologi Minuman Serbuk Biji Alpukat}

\section{Kadar Air dan Kadar Abu}

Sumber kontaminan pada bahan pangan adalah tingginya kandungan air pada bahan pangan. Semakin tinggi kadar air suatu bahan pangan, maka air yang terkandung digunakan mikrobia sebagai pertumbuhannya dan menyebabkan bahan pangan akan mudah rusak atau mengalami pembusukkan (Tiefenbacher, 2018). Kadar abu merupakan salah satu parameter dalam pengujian kandungan gizi makanan, karena dapat menggambarkan kandungan mineral (Lestari dkk., 2014).
Hasil pengukuran kadar air minuman serbuk biji alpukat sebesar 2,6\% dibandingkan dengan Standar Nasional Indonesia (syarat minuman serbuk tradisional dalam SNI 014320-1996) sebesar 3\%, minuman serbuk dalam penelitian ini memiliki kadar air yang memenuhi standar dan layak untuk dikonsumsi. Menurut Burkinshaw (2016), air yang berada di dalam bahan pangan terbagi atas 2, yakni air bebas dan air terikat. Air bebas dapat dihilangkan melalui pemanasan, sedangkan air terikat tidak. Begitupula dengan pembekuan, air bebas dapat membeku, sedangkan air terikat tidak. Dimungkinkan dengan hasil sebesar 2,6\% pada sampel adalah air terikat karena berdasarkan pengeringan menggunak-an spray dryer, air ini tetap ada. Selain itu, air terikat tidak dapat melakukan reaksi kimia dan tidak dapat digunakan mikrobia untuk berkembang biak.

Hasil pengukuran kadar abu minuman serbuk biji alpukat 0,963\% dibandingkan dengan Standar Nasional Indonesia (syarat minuman serbuk tradisional dalam SNI 014320-1996) sebesar 1,5\%, minuman serbuk memiliki kadar abu yang telah memenuhi standar dan layak untuk dikonsumsi. Kadar abu suatu produk dipengaruhi kandungan mineralnya (Lestari dkk., 2014). Kandungan mineral pada biji alpukat, dan dimungkinkan mineral yang dikandung adalah sodium $(\mathrm{Na})$, kalsium (Ca), dan potasium (K) (Talabi et al., 2016).

\section{Total Fenolik, Total Tanin, Saponin dan Daya Larut.}

Tujuan analisa total fenolik, total tanin, saponin, dan daya larut minuman serbuk biji alpukat adalah untuk mengetahui total fenol, total tanin, saponin, dan seberapa lamanya waktu larut minuman serbuk biji alpukat.

Hasil total fenolik minuman serbuk (415,03 mg GAE/100 g serbuk) dibandingkan ekstrak tepung biji alpukat (303,8 mg GAE/100 g serbuk) lebih tinggi. Peningkatan total fenolik pada minuman serbuk biji alpukat disebabkan oleh kadar air karena kadar air pada ekstrak tepung biji alpukat lebih tinggi dibandingkan dengan minuman serbuk biji alpukat.

Peningkatan hasil fenolik diikutin juga dengan peningkatan hasil total tanin. Tepung biji alpukat memiliki kandungan tanin sebesar 8,2\% dalam $1 \mathrm{~g} / 100 \mathrm{ml}$, sedangkan pada 
minuman serbuk sebesar 9,38\% dalam $1 \mathrm{~g} / 100$ $\mathrm{ml}$.

Tanin yang diketahui selama ini banyak ditemukan pada teh. Teh celup yang ada di pasaran memiliki total tanin sebesar 2,5-7,5\% dalam $1 \mathrm{~g} / 100 \mathrm{ml}$, sedangkan pada penelitian ini sebesar $9,38 \%$ dalam $1 \mathrm{~g} / 100 \mathrm{ml}$ total tanin pada minuman serbuk biji alpukat memiliki total tanin yang lebih tinggi dibandingkan dengan produk teh celup yang ada di pasaran (Fajrina dkk., 2016). Produk minuman serbuk biji alpukat tergolong mengandung tanin yang tinggi, sehingga diharapkan minuman serbuk biji alpukat dapat bekerja lebih baik dibandingkan dengan teh dalam hal kesehatan masyarakat.

Analisis daya larut minuman serbuk biji alpukat menunjukkan bahwa waktu yang dibutuhkan serbuk larut sempurna dalam air adalah 14,67 detik. Mengacu pada penelitian Abbas (2018), standar kualitas serbuk ditentukan oleh tingkat kelarutannya. Tingkat kelarutan yang baik adalah tidak melebihi 20 detik. Sebuk minuman biji alpukat dalam penelitian ini sudah memenuhi standar daya larut.

\section{Analisa Warna Minuman serbuk Biji Alpukat}

Salah satu parameter penting konsumen dalam penerimaan produk adalah warna. Menurut Utami dkk. (2018), warna dapat digunakan sebagai faktor kesegaran dan mutu bahan pangan. Alat yang digunakan dalam analisis warna adalah color reader, dengan metode CIE L*a*b.

Hasil yang diperoleh adalah sumber cahaya. Hasil ini disebabkan karena penambahan maltodekstrin, dimana maltodekstrin memengaruhi tingkat kecerahan produk sehingga warna minuman serbuk biji alpukat adalah sumber cahaya atau putih (hasil didapatkan berdasarkan nilai ratarata garis $\mathrm{x}$ : 0,355 dan garis $\mathrm{y}$ : 0,355 pada diagram CIE kromatositi) (Blancard dan Katz, 1995). Produk minuman serbuk biji alpukat memiliki warna normal apabila dibandingkan dengan parameter pada Standar Nasional Indonesia (syarat mutu minuman serbuk tradisional SNI 01-4320-1996).

\section{Angka Lempeng Total}

Tujuan dilakukannya Pengujian angka lempeng total (ALT) adalah untuk mengetahui jumlah mikrobia aerob dan anaerob pada bahan pangan. ALT secara khusus menunjukkan baik buruknya kualitas, umur simpan, kebersihan dalam pengolahan serta kontaminasi antarbahan pangan yang satu dengan yang lainnya.

Analisa hasil ALT minuman serbuk adalah $0 \mathrm{CFU} / \mathrm{g}$. Menurut Standar Nasional Indonesia (mengacu pada syarat mutu minuman serbuk tradisional SNI 01-43201996), minuman serbuk maksimal memiliki nilai ALT sebesar $3 \times 10^{3} \mathrm{CFU} / \mathrm{g}$ dan telah memenuhi standar dan layak untuk dikonsumsi. Hasil yang tidak ditemukannya mikrobia dimungkinkan pada minuman serbuk biji alpukat yang memiliki kandungan senyawa fenolik dan tanin yang tinggi, sehingga menghambat pertumbuhan bakteri.

\section{Analisa Koliform}

Tujuan uji koliform adalah untuk mengetahui keberadaan bakteri koliform menggunakan metode most probable number (MPN). Koliform merupakan bakteri indikator sanitasi yang tidak baik terhadap makanan, air, susu, serta produk turunan susu.

Berdasarkan hasil analisa koliform terhadap minuman serbuk biji alpukat menunjukkan hasil <3 AMP/g. jumlah ini telah memenuhi standar mutu Standar Nasional Indonesia (syarat mutu minuman serbuk tradisional SNI 01-4320-1996). Hal ini disebebkan kerena pembuatan minuman serbuk melalui pemanasan tinggi (spray dryer), sehingga kecil kemungkinan pencemaran koliform. Koliform dapat tumbuhan dan berkembang biak pada suhu $7-60{ }^{\circ} \mathrm{C}$ (Putri dan Kurnia, 2018). Proses penyerbukan dengan menggunakan spray deryer dengan suhu $100{ }^{\circ} \mathrm{C}$ selama 8 jam dimungkinkan membunuh koliform.

\section{Glukosa Darah dan Berat Badan Mencit}

Kadar glukosa mencit diatas $180 \mathrm{mg} / \mathrm{dL}$ dinyatakan sebagai hiperglikemia (Rata-rata kadar glukosa mencit penelitian ini sebelum diberikan aloksan adalah 152,9 mg/dL, dan rata-rata sesudah diberikan aloksan adalah 230,45 mg/dL). Mencit hiperglikemia setelah diberi aloksan, setiap harinya selama 5 minggu diberikan minuman serbuk dengan tujuan melihat pengaruh pemberian minuman serbuk terhadap kadar glukosa mencit. Pengambilan darah dilakukan setiap minggu untuk mengetahui pengaruh pemberian 
variasi dosis serbuk terhadap kadar glukosa darah mencit.

Perlakuan yang digunakan pada mencit ini ada 4 perlakuan. Perlakukan $0 \mathrm{mg} / \mathrm{kgBB}$ (kontrol positif); $180 \mathrm{mg} / \mathrm{kgBB} ; 360 \mathrm{mg}^{\prime} \mathrm{kgBB}$; dan $540 \mathrm{mg} / \mathrm{kgBB}$. Hasil kadar glukosa mencit hiperglikemia pemberian minuman serbuk biji alpukat dengan ke-4 dosis selama 5 minggu dapat dilihat pada Gambar 1.

Berdasarkan hasil pengukuran kadar glukosa darah mencit, pemberian minuman serbuk dosis $0 \mathrm{mg} / \mathrm{kgBB} ; 180 \mathrm{mg} / \mathrm{kgBB} ; 360$ $\mathrm{mg} / \mathrm{kgBB}$; dan $540 \mathrm{mg} / \mathrm{kgBB}$ memiliki beda nyata. Berdasarkan hasil penurunan kadar glukosa darah dalam persen, ditunjukkan dosis $540 \mathrm{mg} / \mathrm{kgBB}$ lebih tinggi yakni $44,54 \%$ dibandingkan dengan dosis $180 \mathrm{mg} / \mathrm{kgBB}$ dan $360 \mathrm{mg} / \mathrm{kgBB}$ sebesar $14,34 \%$ dan 37,83\%. Perbedaan antar-ketiga dosis memengaruhi hasil penurunan kadar glukosa darah mencit. Dosis keseluruhan memenuhi standar Acceptable Daily Intake (ADI) tanin. Menurut Novita (2018), bahan pangan yang bermanfaat sebagai kesehatan yang telah ditetapkan oleh Acceptable Daily Intake (ADI), jumlah maksimal tanin yang dapat dikonsumsi maksimal sejumlah $560 \mathrm{mg} / \mathrm{kgBB}$ perhari. Penurunan kadar glukosa darah pada produk minuman serbuk dibandingkan dengan studi ekstrak etanol biji alpukat yang dilakukan Zuhrotun (2007), dosis minuman serbuk pada penelitian sebesar $540 \mathrm{mg} / \mathrm{kgBB}$ dapat menurunkan kadar glukosa darah mencit hiperglikemia sebesar 44,54\%; sedangkan pada Zuhrotun dosis ekstrak etanol sebesar $980 \mathrm{mg} / \mathrm{kgBB}$ dapat menurnkan kadar glukosa darah tikus sebesar $40 \%$. Berdasarkan data diatas, dosis $540 \mathrm{mg} / \mathrm{kgBB}$ pada minuman serbuk lebih efektif dibandingkan dengan ekstrak etanol biji alpukat. Perbedaan variasi dan keefektifan dosis disebabkan karema adanya perbedaan perlakuan, pada penelitian ini menggunakan air, sedangkan pada penelitian Zuhrotun (2007) menggunkan etanol $80 \%$. Selain itu, penelitian ini juga menganalisa total senyawa (fenolik, tanin, dan saponin) yang memudahkan peneliti untuk mengetahui dosis yang tepat dan aman untuk penurunan kadar glukosa darah mencit hiperglikemia.

Penurunan kadar glukosa darah diduga karena adanya senyawa fenollik, tanin maupun saponin. Senyawa fenol, dapat berperan sebagai antioksidan yang mampu melawan radikal bebas dengan mencegah terjadinya reaksi berantai pengubahan superoksida menjadi hidrogen superoksida dengan mendonorkan atom hidrogen dari kelompok aromatik hidroksil (-OH) untuk mengikat radikal bebas sehingga akan memberikan efek perlindungan dan perbaikan pada sel-sel beta pankreas yang rusak (Dipti et al., 2003). Perbaikan sel beta pankreas diduga mampu meningkatkan kembali sekresi insulin sehingga dapat menurunkan kadar glukosa darah yang tinggi (Babu et al., 2013).

Selain berperan sebagai antioksidan, senyawa fenolik juga mampu menurunkan kadar glukosa darah dengan menghambat penyerapan glukosa di usus halus. Mekanisme yang terjadi adalah dengan menurunkan aktivitas penghantar glukosa, seperti sodium-glucose transporter protein 1 (SGLT 1), glucose tansporter 5 (GLUT 5) maupun glucose transporter 2 (GLUT 2). Kondisi ini dapat membuat glukosa yang masuk ke dalam aliran darah lebih sedikit. SGLT 1, GLUT 5 dan GLUT 2 berperan sebagai transpor aktif yang memfasilitasi penyerapan glukosa di usus halus (Kwon et al., 2007). Pada penelitian lainnya diungkapkan juga bahwa senyawa fenol mampu menghambat aktivitas enzim a-amylase yang berperan dalam pencernaan karbohidrat (Grussu et al., 2011, Kallel et al., 2012). Menurunnya aktivitas enzim a-amylase akan menurunkan proses hidrolisis pati menjadi glukosa, sehingga penyerapan glukosa di usus halus akan terhambat.

Mekanisme lainnya yang diduga dilakukan oleh fenol untuk menurunkan glukosa darah adalah melalui peningkatan ekspresi glucose tansporter 4 (GLUT-4). GLUT4 merupakan transpor aktif untuk memasukkan glukosa dari ekstra ke intrasel yang terdapat pada sel otot dan hati. Hal tersebut didasarkan pada penelitian Cao et al. (2007) yang mengungkapkan bahwa senyawa fenol dapat menginduksi fosforilasi reseptor insulin sehingga menstimulus aktivitas transporter glukosa salah satunya GLUT-4 pada membran sel. Peningkatan ekspresi GLUT-4 dapat mempercepat transpor glukosa masuk ke dalam sel sehingga menurunkan kadar glukosa dalam darah.

Menurut Setiadi et al. (2019), tanin dapat menstimulsi metabolism glukosa dan lemak. Tanin juga memiliki kemampuan hipoglikemik dengan meningkatkan aktivitas glikogenesis. Senyawa ini juga mempunyai 
fungsi sebagai astrigen atau pengkhelat, yang dapat mengerutkan membran epitel usus halus, sehingga mengurangi absorpsi makanan sebagai akibat dari penghambatan asupan glukosa dan laju kenaikan glukosa darah tidak terlalu tinggi. Tanin juga menurunkan glukosa darah dengan meningkatkan penyerapan glukosa melalui aktivasi protein kinase dan phospoinositide 3kinase.Tanin terdiri dari gugus hidroksil dan beberapa gugus yang bersangkutan seperti karboksil untuk membentuk kompleks kuat dengan protein sehingga terbentuk kompleks tanin-protein. Ikatan yang kompleks ini terjadi karena adanya ikatan kovalen, hidrofobik, dan hidrogen (Ani dkk., 2015).
Selain senyawa tanin, penelitian ini menganalisa keberadaan senyawa saponin. Mekanisme antidiabetik saponin adalah dengan menurunkan kadar glukosa darah dan meningkatkan kadar insulin. Aktivitas antihiperglikemia saponin dengan melakukan peremajaan insulin pada sel beta di pankreas, sehingga dapat melepaskan insulin masuk ke dalam darah (El Barky et al., 2017). Saponin juga menunda kematian sel pada pankreas dan mereduksi pembentukan lemak (Choi et al., 2017). Berdasarkan penelitian dimungkinkan senyawa tanin dan saponin, bila dikombinasikan pada dosis yang tepat dapat menurunkan kadar glukosa darah, sehingga diduga ada hubungan yang sinergis antara keduanya.

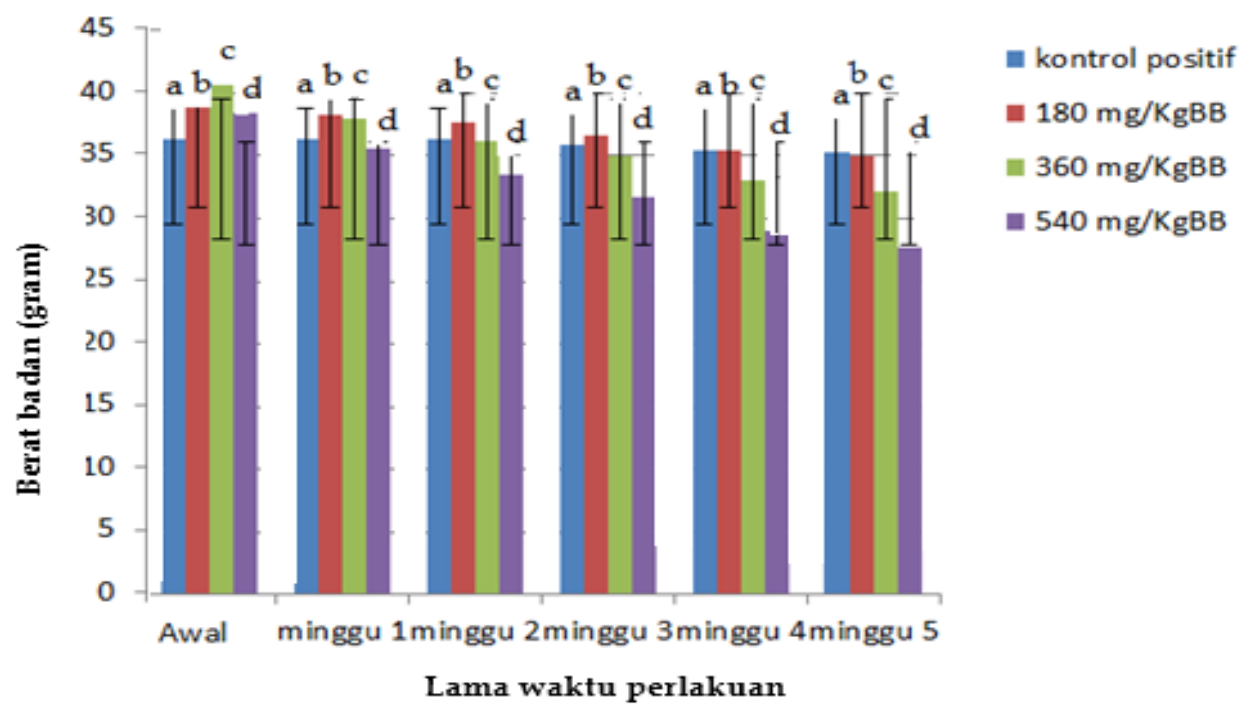

Gambar 1. Perubahan kadar glukosa darah mencit selama perlakuan

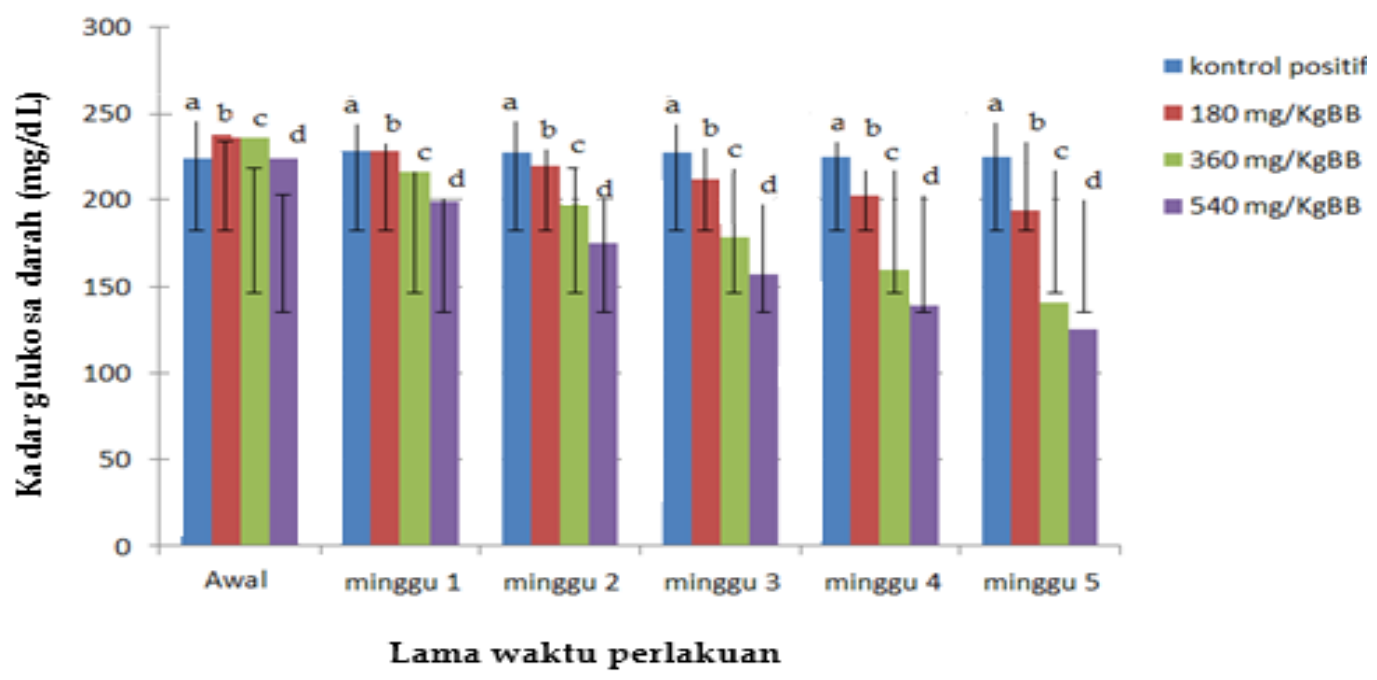

Gambar 2. Perubahan berat badan mencit selama perlakuan 
Selain melakukan pengukuran kadar glukosa darah, juga melakukan pengukuran terhadap berat badan mencit. Sama seperti pengukuran kadar glukosa darah, penimbangan berat badan juga dilakukan setiap minggu agar dapat mengetahui pengaruh pemberian variasi serbuk terhadap berat badan hiperglikemia. Hasil berat badan mencit dengan pemberian minuman serbuk dosis $\quad 0 \quad \mathrm{mg} / \mathrm{kgBB} ; \quad 180 \mathrm{mg} / \mathrm{KgBB}, \quad 360$ $\mathrm{mg} / \mathrm{KgBB}$, dan $540 \mathrm{mg} / \mathrm{KgBB}$ dapat dilihat pada Gambar 2.

Berdasarkan hasil analisa penimbangan berat badan mencit, pemberian minuman serbuk biji alpukat pada rata-rata perdosis sebesar 30,44-34,68 gram. Rentang rata-rata berat badan pemberian serbuk biji alpukat berdasarkan minggu pertama hingga kelima sebesar 30,65-34,95 gram. Penurunan berat badan paling tinggi terjadi pada dosis 540 $\mathrm{mg} / \mathrm{KgBB}$. Hal ini didasarkan pada adanya perbedaan dosis antarketiga dosis sehingga memengaruhi hasil penurunan kadar glukosa darah pada mencit. Studi menyatakan bahwa penurunan kadar glukosa disebabkan karena adanya senyawa fitokimia yang yang memengaruhi metabolisme, sehingga menghambat penyerapan glukosa di saluran cerna.

Penurunan berat badan mencit diperkirakan karena senyawa tannin, menurut Setiadi et al. (2018), tanin dalam hal ini merujuk pada tanin terhidrolisis dapat meningkatkan penyerapan glukosa dan menghambat adipogenesis, bekerja menyerupai insulin, dan dapat meningkatkan aktivitas transpor glukosa ke dalam sel adiposit. Sebelum terjadinya diferensiasi adiposit menjadi adiposit dewasa, pengobatan menggunakan tanin dan insulin menunjukkan penurunan kadar glukosa diikuti dengan peningkatan dosis tanin. Hasil ini menunjukkan bahwa banyaknya jumlah senyawa tanin yang diberikan, maka semakin sedikit adiposit yang berdiferensiasi menjadi adiposit dewasa dan semakin rendahnya aktivitas transport glukosa pada sel.

\section{SIMPULAN}

Simpulan yang dapat ditarik dari penelitian ini adalah Minuman Serbuk Biji Alpukat memberikan pengaruh terhadap mencit yakni dapat menurunkan kadar glukosa darah serta menurunkan berat badan mencit yang diinduksi alloxan monohydrate. Minuman serbuk biji alpukat yang memberikan pengaruh aktivitas antihiperglikemia paling signifikan adalah dosis $540 \mathrm{mg} / \mathrm{kgBB}$.

\section{DAFTAR PUSTAKA}

Abbas, -V.A.A. 2018. Kualitas minuman serbuk instan buah apel manalagi (Malus sylvestris) yang mengandung flavonoid dengan variasi maltodekstrin. Skripsi S-1. Universitas Atma Jaya Yogyakarta, Yogyakarta.

Ani, -A.S., Retno, -I.P., Widiyanto. 2015. Perlindungan protein menggunakan tanin dan saponin terhadap daya fermentasi rumen dan sintesis protein mikrob. Jurnal Veteriner 16 (3): 439 - 447. https://ojs.unud.ac.id/index.php/jvet /article/view/16260

AOAC. (1995). Official Methods of Analysis 16th ed. Washington DC: Association of Official Analytical Chemists.

Babu, -P.V.A., Liu,- D., Gilbertc, -E.R. 2013. Recent advances in understanding the anti-diabetic actions of dietary flavonoids. The Journal of Nutritional Biochemistry. 24 (11). 1777-1789

Barku, -V.Y., Opoku-Boahen, -Y., OwusuAnsah, -E., \& Mensah, -E.F. 2013. Antioxidant activity and the estimation of total phenolic and flavonoid contents of the root extract of Amaranthus spinosus. Asian Journal of Plant Science and Research. 3(1). 69-74. http://www.imedpub.com/articles/a ntioxidant-activity-and-the-estimationof-total-phenolic-and-flavonoidcontents-of-the-root-extract-ofamaranthus-spinosus.pdf

Burkinshaw, -S.P. 2016. Physico-Chemical Aspect of Textile Coloration. John Wiley and Sons, United Kingdom.

Cao, -H.., Avier, -I.., Elly, -M.., Enaraba, R. A. B., Awson, -H., Oves, -S., Oussel, -A., Nderson, -R. 2007. Green tea polyphenol extract regulates the expression of genes involved in glucose uptake and insulin signaling in rats fed a high fructose diet. J. Agric. Food Chem. 55: 6372-6378.

Choi, -M R., Kwak, -S.M., Bang, -S.H., Jeong, J.E., Kim, -D.J. 2017. Chronic saponin 
treatment attenuates damage to the pancreas in chronic alcohol-treated diabetic rats. Journal of Ginseng Research 41 (4): 503 - 512. https:/ / doi.org/10.101 6/j.jgr.2016.09.002

Dipti P, Yogesh B, Kain AK, Pauline T, Anju B, Sairam M, Singh B, Mongia SS, Kumar GI, Selvamurthy W. 2003. Lead induced oxidative stress: beneficial effects of kombucha tea. Biomed Environ Sci, 16(3): 276-282.

El Barky, -A.R., Samy, -A.H., AbeerAbd, E.A.E., Yehia, -H.Z., Tarek, M. M. 2017. Saponin and their potential role in diabetes mellitus. Review Diabetes Management $7 \quad$ (1): $148 \quad$ - 158. https:/ / www.openaccessjournals.com /articles/saponins-and-their-potentialrole-in-diabetes-mellitus.pdf

Fajrina, -A., Junuarty, -J., Stevani, -S. 2016. Penetapan kadar tanin pada teh celup yang beredar dipasaran secara spektrofotometri uv-vis. Jurnal Farmasi Higea 8 (2): $133 \quad$ - 142. https://jurnalfarmasihigea.org/index. php/higea/article/view/145/141

Fardiaz, -S. Margino, 1993, Analisa Mikrobiologi Pangan, PAU Pangan dan Gizi IPB, Penebit Raja Grafindo Persada, Jakarta.

Grussu, D., Derek S. and Gordon J. M. 2011. Berry Polyphenols Inhibit aAmylase in Vitro: Identifying Active Components in Rowanberry and Raspberry. J. Agric. Food Chem. 59 (6): 2324-2331.

Harborne, -J.B. 1987. Metode Fitokimia Pengujian Cara Modern Menganalisis Tumbuhan. Institut Teknologi Bandung. Bandung.

Kwon, O., Peter E., Shenglin C., Christopher P. C, Je-Hyuk L., Michael K. and Mark L. 2007. Inhibition of the intestinal glucose transporter GLUT2 By flavonoids. The FASEB Journal. 21: 366377.

Lestari, -L.A., Puspita, -M.S., Fasty, -A.U. 2014. Kandungan Zat Gizi Makanan Khas Yogyakarta. UGM Press, Yogyakarta.

Malangngi, -L.P., Sangi, -M.S., Paendong, J. J. E. 2012. Penentuan kandungan tanin dan uji aktivitas antioksidan ekstrak biji buah alpukat (Persea americana Mill.). Jurnal MIPA Unsrat Online 1 (1): 5 - 10 https://doi.org/10.35799/jm.1.1.2012.4 23

Novita, -R.P. 2018. Karakteristik konsentrasi tanin pada teh hitam dan the hijau menggunakan spektrofotometer uv-vis. Skripsi-S1. Universitas Jember, Jember.

Putri, -A.M., Pramudya, -K. 2018. Identifikasi keberadaan bakteri Coliform dan total mikrobia dalam es dung-dung di sekitar kampus universitas muhammadiyah Surakarta. Skripsi. Universitas Muhammadiyah Surakarta, Surakarta.

Rifai, -G.,I Wayan, -R.D., Komang, -A. N. 2018. Pengaruh jenis pelarut dan rasio bahan dengan pelarut terhadap kandungan senyawa fenolik dan aktivitas antioksidan ekstrak biji alpukat (Persea americana Mill.). Jurnal ITEPA 7 (2) : 22 32. https://ojs.unud.ac.id/index.php/ itepa/article/view/41128

Rustan, -I.R. 2013. Studi Isolasi dan Identifikasi Bakteri Asam Laktat dari Fermentasi Cabai Rawit (Capsicum frutencens L.). Universitas Hasanuddin.

Setiadi, -R.R., Zein, -A.F. M.Z., Nauphar, -D. 2009. Anthihyperglicemic effectiveness comparison of ethanol extract of soursop leaf (Annona muricata L.) against acarbose in streptozotocininduced diabetic white rats. Journal of Physics: Conference Series 1146012009.

Standar Nasional Indonesia. Syarat mutu minuman serbuk tradisional SNI 01-43201996.

Schanderl, -S. -H. 1970. Tannins and related phenolics. In: M. A. Joslin (Ed.), Methods in food analysis. New York: Academic Press.

Sunusmo, -A.R. 2018. Uji efektivitas antikolestrol ekstrak biji alpukat pada tikus jantan galur wistar secara in vivo beserta skrining fitokimia. Skripsi S-1. Universitas Muhammadiyah Surakarta, Surakarta.

Talabi, -J.T., Olukemi, -A.O., Ajayi, -O.O., Adegoke, -G.O. 2016. Nutritional and antinutritional compositions of processed avocado (Persea americana Mill.) Seeds. Asian Journal of Plant Science and Research 6 (2): 6 - 12. http://www.imedpub.com/articles/n utritional-and-antinutritionalcompositions-of-processed-avocadopersea-americana-mill-seeds.pdf 
Tiefenbacher, -K.F. 2018. The Technology of Wafers and Waffels II :Recipes, Product Development and Know-How. Elsevier Science Publishing, United States.

Utami, -A.P., Sri, -W., Muzuni. Analisis penilaian organoleptik dan nilai gizi cookies formulasi tepung wikau maombo. Jurnal Sains dan Teknologi Pangan 1 (1): $79 \quad-85$. http://ojs.uho.ac.id/index.php/jstp/a rticle/view/1043/674

Zuhrotun, -A. 2007. Aktivitas antidiabetes ekstrak etanol biji buah alpukat (Persea americana Mill.) bentuk bulat. Karya Ilmiah Tidak Dipublikasikan. Fakultas Farmasi Universitas Padjajaran Jatinangor, Bandung. 